\title{
PUBLIC POLICY ON SAFETY AND SECURITY RAILROAD SYSTEM IN INDONESIA
}

\author{
DR. SUWARDI, S.H.*, \\ DR. ROSSA ILMA SILFIAH S.Ag, S.H. *, \\ HERU KUSWANTO SH., M. Hum*
}

Narotama University, Faculty of Law, maswad0634@gmail.com

\begin{tabular}{ll}
\hline $\begin{array}{l}\text { Article history: } \\
\text { Accepted } 20 \text { May } 2019 \\
\text { Available online } 17 \text { July } 2019\end{array}$ & b s t r c c t \\
& Implementation of the new law on railways are yet to be seen due to government regulation as \\
Keywords: & executors being discussed. Government regulations mandated by Law No. 23,2007 set as fast as 1 \\
$\begin{array}{l}\text { Policy } \\
\text { Safety }\end{array}$ & (one) year from the entry into force of the Act. Nevertheless in his closing conditions stated that at \\
Railway & the time the Act came into force. All the implementing regulations of Law No. 131992 declared still \\
Passengers & valid this does not contradict or replaced under the Act contained in Law No. 23 of 2007 in line with \\
& the implementation of regional autonomy and decentralization intended by the Act No. 32 of 2004 \\
& on Regional Government and Government Regulation No. 382007 on delegation of authority from \\
central to local governments.
\end{tabular}

The quality of rail services, especially in economy class lately felt worse. Headway uncertain security condition, and the level of safety continues to decline. Train accident rate continues to rise, where in 2007 there were 116 accidents, an increase from the 2006 total of 107 times. More than $90 \%$ of accidents that occurred in 2007 caused by a Train derailment or overturned (Directorate of Railways, 2008).

\section{Introduction}

In the provision of railway management responsibilities should not all be under the central government, but can be decentralized to regional governments, particularly for domestic passenger services. It is intended to bring rail transport services by rail users. The local government as the regulator and organizer of railway transport is expected to further improve service quality, as well as to integrate the rail transportation system with a network of transportation modes other cities so that the efficiency and effectiveness of service can be improved.

Components in the depot were imported from more than eight countries; eg rail from Japan, carriage from Japan and Germany, lathe from France, and the locomotive from America. The diversity of Train components causes difficulty in treatment, because not all of the specifications of existing components in accordance with the needs and conditions of the rail network in
Indonesia. The inability of PT TRAIN (Indonesia Railways Persero) in determining the appropriate components and similar in order to better facilitate treatment railway technology due to the procurement of infrastructure and facilities under the authority of the Department of Transportation. Therefore, various components of the existing Trains, the cause of the accidents caused by means of railway transport mode is very easy to understand. So that the cause of the accident from the means of transport to get the largest portion of that $34 \%$ of all causes of accidents existing Trains. NTSC in the year 2017 has delivered a variety of causes of railway accidents.

\subsection{Formulation of the problem}

a. How the system of Government policy in ensuring the safety of passengers? 
b. How the transportation system able to function as a public service?

\subsection{Special Purpose Research}

The specific objectives of this study are as follows:

1) Collecting data Train accident during the period of 2014-2017.

2) Calculating the rate of accident on railway accidents in the period Year 2014-2018.

3) Classify the various factors causing Train accident during the period 2017-2018

4) Analyzing the causes of railway accidents in the period Year 2016-2018

\subsection{Urgency (Virtue) Research}

Private vehicles, especially cars is a mode of transport that is not efficient due to the low passenger levels. The transport system is designed for car use is inefficient, especially because of the use of space and a low operating speed to achieve optimal system. From this perspective, it is understandable why the government is seeking ways to implement policies that aim to reduce the use of private vehicles and supports modes of transport that are more environmentally friendly such as public transport by Train (commuter Train, tram or monorail).

Train is an alternative transport which had an advantage, it is competent to serve as a transportation solution in the problem of congestion. Because Train has haulage and relatively efficient using fuel and land compared to other vehicles. In Table 1.1 it can be seen below that the Train has an advantage compared with other modes of transport.

Table. 1.1 Advantages Train Against Other Transportation Modes

\begin{tabular}{|c|c|c|c|c|c|}
\hline Criteria & Train & Car & Motorcycle & Bus & Unit \\
\hline Use Of Land & 0.37 & 0.47 & 0.2 & 0.57 & $\begin{array}{l}\mathrm{Ha} / \text { Billion } \\
\text { Km-PNP }\end{array}$ \\
\hline Energy Consumption & 135 & 765 & 425 & 965 & $\begin{array}{ll}\text { Kcal I } & \mathrm{Km} \\
\text { billion-PNP } & \\
\end{array}$ \\
\hline Air Pollution & 19.6 & 387.5 & 247 & 587.5 & $\begin{array}{l}\text { Gram Co-eq / } \\
\text { Km-PNP }\end{array}$ \\
\hline Noise & & 16.5 & 23.5 & $12.5 \quad 33.5$ & \%impact \\
\hline Security Level & 0.8 & 20 & 14 & 12.5 & $\begin{array}{l}\mathrm{KCl} / \text { Billion } \\
\mathrm{Km}-\mathrm{PNP}\end{array}$ \\
\hline Social Costs & 14 & 78 & 44 & 24 & fee ${ }^{\%}$ transport \\
\hline
\end{tabular}

Source: East Java Provincial Transport Department (2010)

Train facilities superior in energy consumption of air pollution, security level, and social costs. While the category of land use and noise, Train had ranks in 2nd compared with other transportation modes. For haulage, Train also has a special specification. For the transport of goods, it could take up to 10 carriages which is equivalent to 20 containers of 20 feet for one trip. As for the transport of railway passengers were able to accommodate 800 people for a departure. For cities with a population over 1 million, for example Surabaya, it is most definitely help decrease congestion number of Surabaya when the passengers of private vehicles to switch to mass transit such as Trains. From the above explanation, it shows how important the railway for the transport system Indonesia in times to come.

This is because in the future, the Ministry of Transportation has launched a multi mode integration of freight and passenger consisting of buses, Trains, ships and airplanes. As for the mode of transportation cars and motorcycles are not related to the proposed multi mode integration as has been proclaimed by the
Ministry of Transportation. This is evidenced by the impartiality of the government for car and motorcycle modes related to rising gasoline premium of Rp. 4.500, - to Rp. 6.500, - in the year 2017. The increase in fuel prices will continue till the government does not bear the burden of subsidizing fuel prices continue to soar on the world market.

At the National Medium Term Development Plan III (2017 2019) stated that the Government through the Ministry of Transportation will meet the availability, reliability and accessibility of efficient transport infrastructure and PPP scheme (Public Private Partnership) productive. Implicitly, an efficient transport in this case is the railway that results of this study also support the National Medium Term Development Plan of the Ministry of Transportation from 2017 to 2019.

Transport In RPJMN III (Medium Term Development Plan) Year 2017 - 2019 (Source: Ministry of Transportation (2013) 
Ministry of Transportation in RPJMN III 2017 - 2019 also plans to support the Indonesian economy strong and advanced by holding a transport infrastructure and reliable services. The phrase reliable services is related to the safety and security of the railway system in Indonesia. Train role will be increasingly important in the years to come, so we need a public policy development related to safety and security of the railway system in Indonesia which will be appointed for particular goals.

\subsection{Innovation targeted}

Innovation targeted in this study is to support the safety and security of the railway system in Indonesia. Train in recent years often in scapegoats as a mode of transportation that is often experienced such accidents fell from the rail, Train collisions and collisions with other modes of transport such as cars and motorbikes or trucks. Minimum service standards for mass transit is linked with departures and arrivals precise, security crime and safety in railway passenger and freight Trains to various accidents that may occur (Infid, 2008: 10). While that happen within this decade is still the news of the accident and the level of safety of passengers and goods using railway transportation services.

Public policy related to safety and security of the railway system in Indonesia is very important because the Train is one of the leading mode of transportation future will be prioritized by the Government to address the high incidence of accidents on highways and toll roads. Public policy is also very important because it indirectly when the level of safety and security using the railway is very high, then the personal vehicles do not hesitate to choose the railway as a mode of daily transport and will lead directly to a reduction in the level of congestion in major cities in Indonesia. Train also reliable for transport of goods and passengers in large numbers which of course will support the construction and development of science and technology SocioCultural.

\section{Literature Review}

\subsection{Public Policy}

Islamy (2016) explains that public policy is essentially a decision to select a value - the best value of many existing value. The selected best value is the value that is in accordance with the public interest. Policymakers (policymakers) not only serves to create a balance between different interests (muddling through or balancing interest), but he also had to serve as assessor (valuer). That is, he must be able to create the value that can be agreed upon based on the judgment - rational judgment (rational judgment). It is right in order to achieve maximum results.
Inability to articulate the value - the value (especially values values that are contrary) would mean the realization of the interests of society. Or in other words, so that a public policy can be implemented successfully, the policy must be flexible in the implementation process. Design policies or policy decision not a price that can not be done revisions or changes. It is possible to dynamically made changes and improvements to the adjustments referring to the reality on the ground and give priority to public interest considerations.

\subsection{Stages of the Public Policy Formulation}

The series of public policy formulation is a series that is very important to understand, it will be exposed to public policy formulation stage as follows:

a. Problem Formulation (defining the problem)

Winarno (2002: 82) explicitly states that we often find less appropriate problem-solving, rather than finding the right problem. The formulation of the problem is a source of public policy, with the understanding and identification of problems that both the planning policy can be structured, problem formulation made by those affected by the problem or someone else who has the responsibility tanggug and policy makers must have the capacity for it. Public policy process begins with activities to formulate the problem correctly for success in the formulation of public policy or failure in carrying out the formulation is very influential in the formulation of policy matters.

\section{b. Policy Agenda}

Wahab (2004: 40) states a problem to fit into the policy agenda must meet certain conditions, namely: first, the issue has reached a critical point; second, the issue reached a certain level that can be causing any partikulatitas right impact is dramatic; The third issue concerns the specific emotion seen from the interests of the people; Fourth, the issue of questioning authority and legitimacy (legitimacy) in the community; Fifth, the issue concerns a fashionable issue where his position is difficult to explain but easy to feel his presence.

\section{c. Alternative Selection Policies to Solve Problems}

According Islamy (2003: 92), the formulation of policy proposals (policy proposals) is the activity of preparing and developing a series of actions necessary to solve the problem. The process in this activity include: firstly; identifying alternatives; second, defining and formulating alternatives; Third, assess each of the available alternatives, and choose alternatives that satisfy or most likely to be implemented. 


\section{d. Stage Formulation of Policies}

According Islamy (2003: 100) for the validation of the policy is the process of adjustment and acceptance together against the recognized principles and measures are acceptable. In the process there is a policy validation activities undertaken. According to Anderson in Islamy (2003: 100), the approval process begins with kegiataan policies: (a) Persuasion, that attempts to convince others about something the truth or value of one's position and they will accept it as one's own; (b) Barganing, a process in which two or more persons shall have the power or authority to set I adjust at least the goal, the goal that not agree in order to formulate a series of actions mutually acceptable but not ideal for them. barganing includes agreements (negotiation); reciprocity (give and take); and compromise (compromise). At this stage, we can know that the actors struggled that his alternative was received and also interaction with other actors that gave rise to persuasion, and bargaining. Alternative measures taken primarily the result of a joint decision of the various interest groups involved in the policy-making, so as to set a policy. In addition, the policy-setting is done so that a policy can have binding legal force and adhered to by anyone, and shape policies that generated such legislation - legislation, jurisprudence, presidential decrees, ministerial decisions and so forth.

\subsection{Infrastructures}

According to Indonesian Dictionary (980: 786) understanding of the means is anything that can be used as a tool in achieving the goal or intent. Etymologically the word means indirect tool to achieve the goal. In his book Organization and Administration (1988: 82), Suharsimi Arikunto explains that "facilities are all things that can facilitate and expedite obviously given weight of a business". From these limits concluded that the tool is something complementary facilities are indirectly used to facilitate the activities of the organization in achieving goals. Means, something that can facilitate can launch the organizations activities can be objects or money (capital). According Suharsimi Arikunto (1988: 82) outlines the supporting infrastructure divided into two types, namely:

1) Physical facilities, ie everything that can be objects or materialize, who have a role to facilitate and expedite business. Physical facilities also called the material means, for example: vehicles; communication tool; viewer tool; etc.

2) Money facilities, ie everything that is makes it an activity as a result of the workings of the value of money.

Meanwhile, the infrastructure is all that is the main supporting the implementation of a process (Indonesian Dictionary, 980: 786). That is, the infrastructure is a facility used to support and to achieve business or organizational objectives. In other words, the infrastructure is everything needed in the activities of a permanent or fixed such as buildings, courts, halls and so on in an organization or company.

Based on the above, it can be concluded that the infrastructure and facilities are all facilities and tools that can be used as equipment to be used in the implementation of the organizations activities. Meanwhile, the availability of good infrastructure and ideal in the organization, the business activities can be run well. For facilities and infrastructure that do not support will not work optimally in the organization.

\subsection{Definition of Railways}

In the general provisions of Article 1 of Law No. 23 of 2007 on Railways stated that "Railways is an integrated system consisting of infrastructure, facilities, and human resources, as well as the norms, criteria, conditions and procedures for the provision of rail transport". Meanwhile, in the opening of Act No. 23 of 2007 mentioned that the railway as a mode of transportation in the national transportation system that has the characteristics of the transport of mass and its own advantages, which can not be separated from other modes of transport, need to develop their potential, and enhanced its role as a link region, both nationally and internationally, to support, encourage, and drive the national development in order to improve people's welfare.

In line with the above explanation, according to Nasution (1996: 64) Train contribution to the development of the economy and society is enormous. Train apilah who started transportation of goods in large quantities at low cost, which stimulates the growth of industry, mining, trade, and other activities in the community. Railway transport has several advantages compared with other types of transport, namely:

a) Capable of transporting cargo in large numbers

b) Being able to travel long distances. Increased far distance becomes more efficient and lower cost.

c) Travel itinerary with a high frequency can be implemented.

d) Rarely congestion because all the facilities are owned by one perusahaan so that the provision of services more assured smoothness.

e) Can provide a better level of service than the bus. 
From the above explanation can be concluded that the railway is one mode that has the characteristics and special advantages primarily in its ability to transport both passengers and goods in bulk, saving energy, saving in the use of space, has a safety factor is high, and the level of contamination is low and more efficient compared with other modes of road transport to transport over long distances and for dense traffic areas, such as urban transportation.

Goal of railway development is prioritized to improve the performance of services, especially the safety of transport, through a reduction in the rate of accidents and fatalities due to accidents at level crossings with roads and security management operations on all the main traffic is solid, and the smooth mobilization of transportation of goods and services. Broadly speaking railway development objectives are:

1) recovery reliability with strategic priorities and a solid track

2) optimal and recovery of existing networks, development of new networks and increased capacity

3) revise legislation in the field of railways

4) increasing the quality of planning and funding

5) the increasing role of local government, state enterprises and the private sector in the field of railroad;

6) increased human resources and mastery of technology

7) standardization of national railways in an integrated manner so that the continuity of investment, operation and maintenance of national railway infrastructure and facilities can be achieved efficiently.

The direction of development of railways, among others, as follows:

a) Improving transport safety and quality of care through the restoration of conditions of service and means of transport railway infrastructure.

b) Performance audit of the infrastructure and facilities as well as human resources of the railway operator.

c) Enhancing the role of national and local railway transportation, and

d) improve transit service strategy more competitive in intermodal and intramoda. e) Improve service capacity and quality, especially in saturated corridors and strategic corridors with reference to Sistranas

f) Increase frequency and provide affordable Railroad (KA/Train) transportation services.

g) Carry out the planning, financing and performance evaluation of integrated railways, and supported sustainable development of data systems and more accurate information.

h) Continuing reforms and institutional restructuring and BUMNserta revision of legislation in the field of railways (Act No. 13 of 1992 and its implementation regulations).

i) Increasing the participation of local governments and private in the field of railways.

j) Improving railway human resources and technological development of the national railways.

\subsection{Definition of Railway Infrastructures}

In Act No. 23 of 2007 on the management of the railways in Article 1 stated that railway vehicle is a vehicle that can move on the rail road. By type railways facility as mentioned in Article 96 consists of:

a. locomotive;

b. Train;

c. carriages; and

d. Special equipment.

Based on the above understanding, that means the Train is anything that can be run in the activities of railways and as a major factor implementation of railway activities, such as Trains and locomotives. In this case, Trains and locomotives as a means of transportation to move move - move from one place to another. Railway facilities is the main organizer and principal in the activities of the railway, the railway activities can be conducted properly depending on the management of the railway facilities.

Under the general provisions of Law No. 23 of 2007 on the management of railway infrastructure mentioned in article 1 of railways is a railway line and railway operation facilities so that Trains can be operated. The railway line itself is a path consisting of a series of plots of track that includes the benefits of space railway lines, railway lines owned space, and a railway line supervisors, including the top and bottom, which is intended for rail traffic. Organizers of railway infrastructure itself is a party to organize railway infrastructure. Organizers of the public railway infrastructure as defined in Article 18 of Law No. 23 Year 2007 
conducted by enterprises as an organizer, either individually or through cooperation. In the absence of entities that organize railway infrastructure, the central government or local governments could organize railway infrastructure. It can be concluded that the railway infrastructure is everything that is needed in railways activities and as a major factor implementation of railway activities which are permanent, such as railway and other railway operation facilities. That is, the permanent infrastructure can not be moved from one place to another. It can be concluded that the railway infrastructure is everything that is needed in railways activities and as a major factor implementation of railway activities which are permanent, such as railway and other railway operation facilities. That is, the permanent infrastructure can not be moved from one place to another.

According to Article 1 of Law No. 23 of 2007 on railways explained that the Train operating facilities are all necessary facilities so that Trains can be operated. Railway operation facilities include signaling equipment and telecommunications equipment. Rail infrastructure is supporting the organization of the railway. commit to the user. Based on the description above railway infrastructure can be defined as everything that shaped the facilities and tools used to support the implementation activities of the railways that are able to move that Train and locomotive and permanent such as rail and other railway operation facilities.

\subsection{Transportation Safety and Security in Sistranas}

Minister of Transportation has issued Regulation of the Minister of Transportation No. KM 49 Year 2005 on the National Transportation System (Sistranas). Sistranas was issued with the intention of setting guidelines and the development of transportation, in order to achieve effective implementation of national transport and efficient. The Sistranas formulation also take advantage of opportunities and consTraints attention internationally, regionally and nationally, both in terms of regulators, operators, service users, as well as from the community, with the goal of realization of the implementation of an effective and efficient transportation. Sistranas is organized transport order system of unity consisting of road transport, railway transport, river and lake transport, pedestrian transport, sea transport, air transport,

Sistranas purpose is the realization of an effective and efficient transportation to support and simultaneously drive the dynamics of development, increasing Trainn mobility of people, goods and services, helped create a national distribution pattern of stable and dynamic, as well as supporting the development of the region, and further strengthen the development of the society, nation and state in the context of the embodiment of the archipelago insight and improved international relations.

Sistranas target is the realization of the implementation of an effective and efficient transportation. Effective in the sense of safe, high accessibility, integrated, insufficient capacity, orderly, smooth and quick, convenient, timely, convenient, affordable rates, orderly, safe, and low pollution. Efficient in the sense of the public burden of low and high utility in one unified national transport network. Congratulations, in the sense of avoiding the operation of transport of transportation accidents due to internal factors. The situation can be measured which are based on a comparison between the number of occurrences of accidents on the amount of movement of vehicles and the number of passengers or goods. Safe, in the sense of avoiding the operation of transport of transportation due to external factors in the form of natural disasters, human disturbance, and other disorders. Source: KM Communications No. 49 (2005: 9)

In the section on Sistranas problem identification - precisely on page 61 - indicated that the safety and security of transport is a problem No. 2 after the network infrastructure and services. This shows that the Government is committed to give priority to safety and security for the people of Indonesia in terms of transport. This is because the government is aware that:

a) Level of safety and security of transportation is still quite alarming both for passengers and goods.

b) The role of transport in support of national security, prevention of smuggling, drug eradication and prevention of terrorism is still not optimal.

The government also strive to increase the safety and security of transport in the following ways:

a. Transport Safety Improvement

1) Improve transport safety

a) Realizing the high level of transport safety.

b) Acquaintances of potential safety issues and their causes are carried out by continually improving the reporting system concerning the accuracy of data and information relating to symptoms of irregularities.

c) Review (safety audit) for each new design of transportation to detect possible problems regarding safety, and conduct special studies for facilities and infrastructure that 
already exists if there is happen problem that is considered serious about safety and accidents.

d) Ensuring a continuous basis so that the government, law enforcement agencies and the private sector to coordinate and allocate a greater source of funds for the areas of safety, including public awareness, law enforcer and training of public and private sector workers related to improving safety.

e) Provision of transport must meet the eligibility requirements, safety, security and traffic rules by observing laws and international conventions in force and has been ratified.

f) Striving for the maximum increase public awareness and vehicle crews, selecting and testing the crew serta enforce the law violators.

g) Reduce the risk of accidents for workers in the transport sector

h) Increase the coverage, quantity and quality of data / information meteorology and geophysics in particular for shipping and aviation activities.

i) Improving search and rescue capability shipping and aviation accidents.

j) Each service provider (operator) required transportation insurance cover to bear the risk of the safety of passengers and goods transported.

k) Increase empowerment weighbridge function as a means of controlling overload that can result in damage to the road and traffic safety.

b. Transportation Security Enhancement

1) Improving transport security in support of national security and defense.

a) Plan of transport as far as possible the entire facility is suitable and can be used to support the implementation of state defense and security.

b) To work together to identify and prepare for the transportation needs in the event of natural disasters and other accidents.

2) Improving transport security in support of the eradication of drugs.

a) Increase the ability of prevention of entry of drugs through ports, airports and roads.

b) To coordinate to prevent the movement of illicit drugs in the country.

3) Improving transport security to prevent terrorism.

a) Applying the tools of new generation explosives detection sensitive to detect and thwart terrorism. b) To work together to analyze and improve security facilities against terrorist attacks, pirates and other criminals.

c) Applying international standards and conventions to enhance transport security.

\subsection{Preliminary Study}

Preliminary study on public policy related to Railways Revitalization has been carried out in 2014. The essence of the preliminary research that has been done is as follows: The construction of railways in Indonesia has entered a new phase with the enactment of Law No. 23 of 2007 on Railways. Enforcement has a huge impact on the railway operation, not only at the operational level but also at the institutional and policy aspects. Given the complexity of the problems facing the national railway system, it is necessary to determine policy priorities.

This material is trying to formulate a national railway policy priorities which should be taken in the application of Law No. 23 of 2007. The determination of the policy priorities based on expert opinion and processed using AHP. The results show that the policies that get the biggest priority is improving safety and security of Train travel, followed by the standardization of railway infrastructure. The experts chose the policy as a priority because of the impact of significant and lasting impact. This research is expected to contribute in two areas, namely ensuring that the policy paper on the railways and provide input for the Railroad Directorate General in the preparation of regulatory and policy railways.

\section{Research Methods}

\subsection{Flow Chart Research (Fish Bone Diagram)}

In the Year 2013, the research team conducted a study identifying the urban transportation system planning policies Surabaya. This research resulted in that to Surabaya, which already has a population of 3 million, the research team recommends urban transport ideal is to utilize modes of transport trams, previously never existed until 1976 for the corridor north - south of Surabaya and suggested the construction of monorail tracks for corridors east - west Surabaya.

In 2014, the research team has been studying the prioritization of railway policy in East Java province. This study resulted in that the government has not siding fully on road-based public transport ie railway tracks. So that the budget allocation for the development of railway infrastructure is still very limited. It 
makes railway services for passengers and goods have not reached the ideal level. So that passengers still prefer to use transport cars and motorcycles to make visits to various cities in East Java. It certainly would cost the country in terms of subsidies.

For the years 2019 - 2021, the research team will conduct research with the title as follows:

1. 2019: Public Policy Priorities About Safety and Security Systems Railways East Java, the research sites: East Java Province, the measured results indicators: The formation of policy documents Railway Safety and Security Systems in East Java.

2. 2020: Proposed Policy Land Transport Safety and Security in East Java Province, the location of research: East Java Province, the measured results indicators: The formation of policy documents Land Transport Safety and Security in East Java province.

3. 2021: Proposed Management System Development and the National Transportation in East Java, the research sites: East Java Province, the measured results indicators: Establishment of document Proposal Management System Development and the National Transportation in the province of East Java.

\section{Discussion}

\subsection{Railways in Indonesia}

Railway means of transport such as vehicles powered by motion, either walking alone or coupled with other vehicles, which will or is moving on rails. Train is a means of mass transportation that generally consists of a locomotive (vehicles with running own dynamics) and circuit wagon or carriage (coupled with other vehicles). The series of Trains or carriages are relatively wide so as to accommodate the passengers and goods on a large scale. Because of its nature as an effective mass transit, some countries try to utilize the maximum as the primary means of transportation overland transport both within the city, intercity, and between nations.

\section{Indonesia Railroad Conditions}

The Train is one of mass transportation, Train their purpose is to facilitate the movement of people or goods in bulk. Thus, the function of railways for public services. But there are still many problems or challenges still faced by railways. The balance in the public interest, means service not only pay attention to commercial interests, or serve only partially certain segments of society, but also for public services and all segments of society. There are 4 main railroad pillars namely: safety, punctuality, service and comfort.

There are several of its products:

1. Kereta Api (TRAIN) Passenger, which is divided into three classes (Executive, Business and Economics).

2. Train Travel, to support tourism, PT. Kereta Api (Persero) provides services charter a special Train tours are also a variety of purposes such as meetings, weddings, birthdays, etc. on top of Railways towards various destinations.

3. Goods Trains, Trains specially tailored to the specifications of the product, which is PT. Kereta Api (Persero) has a carriage that is used for coal, pulp, Crude Palm of oil, fuel, container, Parcel BHP, Over Night, Cement.

4. Asset Utilization, addition of Passenger Transport and Freight, PT. Kereta Api (Persero) also empowers non-production assets to be commercialized to external parties. Some products rental of non-production assets.

In Java, there are three main service traffic, namely: JakartaBandung, Jakarta-Semarang-Surabaya (called across the north), and Jakarta-Yogyakarta-Surabaya (called across the south). While in Sumatra, there are three sub-networks TRAIN separated from each other namely: a sub-network of northern Sumatra, a sub-network of West Sumatra, and a sub-network of southern Sumatra.

Indonesian railroad conditions is experiencing a cyclical decline. Although some modern locomotive has been said, but the Trains management system is still very bad. This is evident from the management of railways is not maximum. There are a lot of poorly maintained locomotives, Train cars so dirty and unfit for use, to the poor condition of the rail. Public services are also lacking professional, is evident from the inability of PT. KAI (Indonesian Train Persero) overcomes the explosion of passengers that occur every day. PT. KAI has not been able to become a facilitator for people in public transport. Supposedly

PT. KAI must find a solution of the overcomes that could cause injury or death, if the cargo Train beyond normal limits to the number of passengers riding on the roof of Railways. However railways in Indonesia still have to be developed in the future, both for long-distance transportation as well as at the local level. However, the problem is quite disturbing railway today is the high rate of accidents. 
Quite the high loss of life and socio-economic losses due to the Train accident has caused the service image and railways management declined. Safety performance increasing the demand and the attention that must be improved. The cause of the high rail accident is an accumulation of many factors, including regulatory issues, management, infrastructure conditions and facilities. Railroad facilities include locomotives, Trains, cars, KRL (Electricity Train), and KRD (Diesel Train). Rail road infrastructure that exists today in general are still single track. New double track is available in the Jakarta-Cikampek, JakartaBogor, Padalarang-Bandung, and Surabaya Kota-Wonokromo. Existing rail line has a load of between 9 to 18 tons, which is capable of supporting Train speeds between $60-110 \mathrm{~km} / \mathrm{h}$. Length of the railway in Java that still operated along 3. $216 \mathrm{~km}$ and in Sumatra along 1,348 km. Most of the track condition was less worthy of operation so it is prone to accidents. In order to reduce the number of railway accidents, Train safety factor issue the highest priority, to establish improved safety there are four strategies as follows:

1. Reducing the frequency of Train accidents by maintaining the quality of infrastructure and facilities, as well as related quality of human resources.

2. Control of passengers on the roof of the Train through law enforcement and sterilization station.

3. Application of No Go Item explicitly.

4. Socialization safety culture.

If the strategy to reduce the level of accidents is only normative as has been done previously which does not reflect a sense of crisis, the efforts to suppress the accident rate will not be effective.

\subsection{Railway Services in Indonesia}

Service is something that really determines the comfort of the community which will influence the interest of the community to choose the public transportation equipment that will be used. If the service provided is bad, it will minimize the interest of the community to use the transportation. while if the service provided is good, it will increase the interest of society. Particularly railroad field in Indonesia, many services provided related to two aspects, namely services intra (within) and extra services (outside) Trains. Although different, but both of these things are interrelated in increased convenience for rail users. If just one of these aspects that look good, it can be ascertained degree of comfort and satisfaction Train service users in Indonesia will remain low. Each period, the operator of rail services in Indonesia continues to clean up and improve their services. One way that has been done by PT. KAI is to provide ticket booking services using the online system. This method is used so that people no longer need to spend time waiting in line for hours just to get a ticket. In addition other forms of reform undertaken by PT. KAI is to open a new class, namely AC (Air Conditioner) economy class. This class is indeed a very powerful breakthrough to increase the interest of the community to use the services of PT. KAI.

Even so there are still many things that the society should be corrected. Starting from ticketing system. Although it uses the online service system, but the public is not satisfied. Because it is still inadequate number of tickets given to the public. It can be seen from the facts on the ground. There are still many passengers stranded due to lack of public knowledge about this online system.

If the services provided by PT. KAI has been able to serve the community to provide satisfaction in accordance with what was expected, while that of services provided can be said to be satisfactory.

\subsection{External Services Railway}

One of the facilities is provided relating to the railway is the railway station to place the up and down of passengers. According to Law No. 23 Railways Train station as referred to in paragraph (1) letter $b$ serves as the Trains leaving or ceasing to serve:

\section{Up and down passengers}

2. Loading and unloading goods; and / or

3. Requirements for train operations

Article 133 Paragraph (1) of Law No. 23/2007 mentions in organizing the transport of persons by rail, organizer of the railways facility shall prioritize the safety and security of persons, services in the public interest, to adhere to the scheduled departure of the Train. In Article 137 of the same law states the transport services by rail must meet minimum service standards ranging from service at the station of departure, en route, to arrive at the destination station. But the implementation is still a lot of complaints from consumers regarding SPM KRL (Train Minimum Service Standard). (Yudi, 2012). 
For the situation of railway companies who have recently suffered a setback, service and infrastructure also contributed to decline in quality. Starting from ticket selling service, safety, comfort, order and the attitude of the station attendants. The decline in service at the station is influenced by several factors, among others, the lack of discipline of both officers and passengers, or catastrophic natural factors and individual behavior that is in the station. The security must be considered in the station includes crime that threatens the security of the property. It is given that in the crowd of passengers at the station there is the thief that threatens possessions passengers. In addition to the crime, and broad platform helped shape a contributing factor to the decline in the level of security at the station.

\subsection{Internal Services Railway}

Mirroring both the poor quality of service can be seen from the facilities on the Train. Although Trains have their own classes (economic, business, executives), all class must equally meet the standards of passenger comfort and satisfaction. Especially rail has the distance away. Comfort must be considered in comparison with rail travel is near.

\subsection{Solution Problem Railways in Indonesia}

Raised the issue of the problems mentioned above is derived from a trivial matter to an issue which requires further treatment. Problems are resolved gradually to prioritize urgent. The solution may soon be done is, rejuvenation of aged railway with handling technicians in detail to the whole Train, from the Train body, engine, until the supporting facilities in the Train. Route system is an important factor in the improvement. With state of the rail that is still sturdy and long-lived, will reduce the threat of accidents. On the other of the above, the multiplication of the fleet Train with the same route will facilitate the arrival and departure control systems without having wait too long. Stations are less suitable for use can be a significant problem. On the other hand the natural problems which may come suddenly, despite being predicted to also be a difficult problem to deal with, just be anticipated.

Government budgeting more, preferably for improved infrastructure for railway Trains can be one alternative to ease traffic congestion in major cities. With more attention to Train, will bring surplus to the government, if a lot of people who prefer to use the Train for mobility. Worse yet if it enters the atmosphere widths more passengers choose to use the Train should be further enhanced comfort.
The problems to be those reluctant or less interest in using rail services are supporting facilities in the Train. They think that if they get less amenities to create a comfortable during the trip. Providers should be more facilities to maintain good and make it comfortable. Cleanliness is one of the reasons of discomfort in the Train. Different classes, different treatment facilities are also clean, although his seharus permanent differences existing standards.

\section{Conclusion}

The number of accidents in Indonesia from 2007 to the Year 2011 experienced ups and downs. In 2007 and 2011 respectively are $14,8,8,10$ and 1 accident. There were 10 accidents in 2010 with the number of 42 victims died and 47 were injured. While the average index of the highest Train accident occurred in 2007 which amounted to 0,302 . Train accident type is divided into three namely plummeted / rolled (64\%), collision between Trains (29\%) and other causes as much as $7 \%$. While the cause of the accident can be divided into 5 that the means $(34 \%)$, infrastructure $(32 \%)$, human resources / HR (17\%), operations $(10 \%)$, and external (7\%).

The goal is to try to propose the development of policy related to the safety and security of railways in Indonesia in terms of facilities, infrastructure, human resources, operations and external causes that the number of railway accidents in the premises is at its most minimal. While specific targets to be achieved in this research is to attempt to synergize the fields of science and civil engineering transportation law to provide policy-related view of the safety and security of railways in Indonesia.

The stages to be examined are analyzing elements of Government policy related to the security and safety guarantee system in utilizing train services and its legal basis.

Recommending the legal aspects of the safety and security policy system for users of railroad transportation services in Indonesia so that they will get a guarantee of higher public awareness for using train facilities. The method used in this research is to collect the facts railway accident causes both secondary and primary data. After the Train accident facts gathered, it will be implemented sorting cause of the accident and provide solutions and anticipation of the above-mentioned causes of railway accidents. 
From the results of this study will be expected that Indonesia Government had a very big effort to favor rail transport modes. The effort is good for the allocation of new technology investment funds for facilities and infrastructure and also for Training and human resource development. So that future Train accident causes of facilities, infrastructure and human resources can be minimized and the cause of the accident is likely to occur only on operational and external causes.

\section{Suggestion}

Judging from the number of accidents in the world a wide range of transportation in Indonesia today require the transportation management control, especially on how the role of the control or supervision of the government and society as transport users. Plus more if the terms of some of the information as well as real data in the field that exist today, for example:

1. The reality on the ground in the discovery of the use of Train parts that have been used turned out to be more use of secondhand goods, in terms of the process of replacement of parts Train components, only able to using obsolete spare parts and then repaired again and reused as spare parts replacement. example:

Data obtained from PT KAI to mention that for parts railway wheels used on the Train in economy class and business class on average use of spare parts railway wheels used, which is where the parts repaired of the wheels which only strong for 8 years restored for use for decades.

Then some of the railroad cars that exist today, even reaching up to the executive class, there are some train cars that used to be old railroad cars that are very outdated and then the remodel is formed in such a way as to form executive-class carriages and in the end to be reused with labels new train carriage.

2. The reality in the field needs to be an increase in resources and an increase in overall transport capacity in the sense that increasing resources here is able to increase transportation needs in terms of the number of existing fleets, until the fulfillment of spare parts capacity is repaired. best to be used as a means of transportation and this will impact on reducing the level of risk of accidents that exist in rail transportation equipment and other means of transportation.
Increased resources can also be interpreted as an increase in human resources, for example as follows: the government as a determinant of transport policy to be able to know overall how the level of human resources who work on the processing of transport services are able to work well, not only in accordance with service procedures transportation but also able to understand how to control the prevention of accidents there to reduce the error rate will be undertaken by humans. By doing educational and Training to improve the work ethic of the perpetrators manager of transportation services. Examples of the need to increase human resources in the sector of transportation management in Indonesia: NTSC (National Transportation Safety Committee). Recently made some very fatal mistakes, for example giving permission to a place that is dangerous for journalists just to find the most recent news, so from here we can conclude that NTSC needs to improve the quality of work by not ignoring the safety of the people who work for improve transportation quality and transportation users.

3. The reality in the field is that there are still many illegal payments (illegal levies) on railroad transportation facilities, for example at the Rangkas - Belitung train station, the service operator PT. KAI provides a ticket fee for the Rangkas department to Belitung in the amount of Rp. 1500-Rp. 2000, but the reality in the field is that there are wild ridges in addition to the cost of the ticket, so the cost of one passenger is Rp. 2000-Rp. 4000. This shows that the management of the station is still far from the perfection of existing regulations.

The main thing that must be done to improve the quality of processing railroad transportation and being able to reduce the level of accidents is by conducting "supervision". In this case the role of supervision can be carried out both by the government and the community as users of the transportation service. However, according to the legislation in force in this country, the main proposition in the process of supervision and the main person in charge is the government, so the government is the policy maker in the supervision and management of transportation.

In addition to accelerating existing transportation improvements, overall there needs to be a change in the basic management of transportation management in Indonesia, or the need for "Regulatory Reform" in the sense that there is a need for very poor management improvements at this time. The main points that can be done in the near future are: the need for evaluation is how the role of the government, especially in determining the direction of policies to improve the quality of resources and the quality of facilities and infrastructure supporting transportation in Indonesia. 


\section{References}

1. Dunn, William N. (1981), Public Policy Analysis: An Introduction, London: Prentice Hall International, Inc.

2. Dunn, William N. (1999), Public Policy Analysis, YogyaTrainrta: Hanindita

3. Hardian, MO, Gani, AZ and Sutarman (2008), Determining National Railways Policy Priorities, JaTrainrta: Department of Industrial Engineering University Gunadarma

4. Islamy M. Irfan (2001), Monograph Series Public Policy: Policy Analysis, PPSUB

5. Islamy, M. Irfan (2002), Principles - principles of State Policy Formulation, Second Edition, First Printing, JaTrainrta: Bina Script

6. Ministry for Research and Technology (2006), Indonesia from 2005 to 2025, a White Paper on Research, Development and Application of Science and Technology on Technology and Transport Management, JaTrainrta: Ministry of Research and Technology

7. Nasution, HMN (1996), Transportation Management, JaTrainrta: Ghalia Indonesia

8. Sulistio, EB and Dian Traingungan (2012), Policy Formulation Study of Urban Planning SistemTransportasi in Bandarlampung, Bandarlampung: Department of Public Administration, Faculty of Social and Political Imu

9. Wahab, Abdul Solichin (1997), Policy Analysis, JaTrainrta: Earth Literacy

10. Winarno, Bob (2002), Theory and Public Policy Process, YogyaTrainrta: Media Pressindo

11. YustiTrainsari, Malinda (2011), Management of Railway Infrastructures PT. Kereta Api Indonesia (Persero) Regional Operations (DAOP) VII Madiun, SuraTrainrta: Department of Administrative Sciences
Faculty of Social and Political Sciences, University of March 